\title{
Invasive Micropapillary Breast Carcinoma
}

National Cancer Institute

\section{Source}

National Cancer Institute. Invasive Micropapillary Breast Carcinoma. NCI Thesaurus.

Code C36084.

An invasive breast carcinoma characterized by the presence of clusters of malignant cells located within artifactual clear stromal spaces that resemble vascular spaces. 